\title{
HUMAN RESOURCE PLANNING IN NEPALESE BUSINESS ENTERPRISES
}

\author{
Manoj Kumar Chaurasiya \\ Department of Management, TU, Thakur Ram Multiple Campus, Birganj, Nepal
}

\begin{abstract}
Human resource planning is a process of determining organization's future human resource requirements and course of action needed to satisfy those needs to achieve organizational objectives. It also ensure and determines that it has right number and right kinds of people at right places, at right time performing work in the organization effectively and efficiently for which they are most economical and useful. It tries to keep balance between organizations human resource supplied with required stable and capable people when they are demanded. This article deals with the concept, objectives, relevance of human resource planning. More ever it also identifies benefit to be taken by the use of human resource planning and highlights the human resource planning practices in Nepalese business enterprises.
\end{abstract}

\section{Keywords}

Human resource; employment planning; career development; succession planning; job analysis

\section{Introduction}

Planning is the guidelines and roadmap for work to be done in future to achieve certain stated objectives. Planning decides in advance about what to do, how to do it, when to do it and how is to do it. It provides the standard to be achieved.

Human resource is one of the most vital and active resources of an organization. we cannot imagine the existence of any organization if there is no human being or manpower. The need of manpower is immense for the continous operation of the organization. Therefore, human resource requirement should be the basic task for any firm or company in order to perform its scheduled activities and achieve the predetermined goals in todays dynamic and complex environment. All human and Non-human resources are mobilized altogether to achieve the goals and objectives of the organization. In an organization by the term human being we mean the one and only active resources of the organization which is concerned with performing job. Finally human resources is understood as those people who work in an 
organization for reward and benefit or say to get something having the special knowledge , skill, ability and experiences to perform the assigned task effectively and efficiently.

Human resource planning is entry point of human Resource management. It is concerned with people working in an organization. Human resource planning is one of the most important and crucial tasks in successfull human Resource management program because it helps to ensure the needed manpower for organizational goal. It is also the complex task of identifying human resource needs and the actions to be taken to satisfy the needs.Human resource planning is also called manpower planning or personnel planning or employment planning. Traditional manpower planning means at attempting to reconcile an organization's need for human resources with the available supply of labour in the local and national market only. In essence, human Resource planning initially seeks to estimate the current and future need of employment.

Manpower planning is a complicated process especially in large organization. It requires specialized knowledge and expertise. Human Resources are considered the most valuable yet most volatileand potentially unpredictable resource, which an organization utilizes. The issues that human resource department may compulsorly address as described by Beard and Holden (1995) are:- How many employees does the organization currently employ? What is the age profile of our employees? where in the organization are these employees to be found? Which are the biggest departments in the organization? What skills do our employee possess? How many employees on average leave the organization every year? In which areas of our business do we tend to 'lose' more employees?

Morever, Human resource planning may be defined as process of knowing or identifying what kind of people should be recruited to ensure the quality performance of the organization. It tries to ensure that required competency is coped with organizational mission, vision and strategic objectives. It also determines an organization human resource needs. It also tries to keep the organization supplied with required,stable and capable people when they are demanded. It identifies what is to be done to ensure the availability of human resource need to achieve stated goals and objectives within given environmental constraints. Human resource planning must be linked to the overall strategy of the organization.

Human resource planning is a complex, continous and never ending process which maximum utilizes available human resources and matches human resource demand and supply. It also determines the right number and kinds of people, at right places, at right time and helps to transform the organizations objectives and plans into number of workers needed to meet these objectives. Thus, human resource planning cited by Kharel (2012) is aimed at balancing demands and supply of workers, controlling cost of human labour, formulating policies on transfer, succession, relocation of man power, ensuring right kind of people at right time and at right place.

\section{Objectives of human resource planning}

Chabra(2001) describesthemajor Objectives of Human resource planning in an organization are as below: To ensure optimum use of human resource currently available in the organization, to balance in the distribution and allocation of human resource, to asses/ forecast future skills requirement of the organization overall objectives, to provide control measure to ensure availability of necessary resource when required, to control the cost aspect of human resource, to formulate, transfer and promotion policies.

\section{Relevance of human resource planning}

Human resource planning aims at fulfilling 
or meeting the objectives of human resource requirements. It helps to mobilize and utilize the available human resources with all other resources for the productive activities. Human resource planning is important process aiming to link business strategy and its overall operation. Human resource planning is the essence of organizational effectiveness and it anticipates not only the required number and kinds of manpower but also determine the action plan for acquisition, development, utilization and maintenance of human resource. The Relevancy of human resource planning in organization is as below:- To determine the future personal needs, To Recruit and select the most capable personnel, To determine career development programmes to the development of human resource, maximum utilization of human resource, To provide effective motivation, To cope with change, To avoid uncertainty, To maintain good human and labour relations, Regular job performance and job satisfaction, achievement of organizational goals, minimizes future risks and control employee in an organization, Helps to develop human resource inventory or skills of inventory, Provide equal employment opportunity, Provide foundation to human resource management functions.

\section{Benefits of human resource planning}

Human resource planning is a systematic approach to ensure that the right people will be in right place at the right time so that organization can achieve its overall objectives. It provides information about the existing strengths and weaknesses of the people in the organization as well as the kinds of skills to be developed. Thus, by the use of human resource planning its main benefits as described by Ivancevich and Glueck (1983) are:-

(a) More effective and efficient use of people at work:-

Human resource planning should precede all other Human Resource management activities. For example, how could the human resource managers schedule recruiting if they did not know how many people were needed? How could they select effectively if they did not know the kinds of applicants needed for job openings? Careful analysis of all human resource management activities shows that their effectiveness and efficiency, Which result in increased productivity, depend on human resource planning.

(b) More satisfied and better developed employees:-

Employees who work for organization that use good human resource planning systems have a better chance to participate in planning their own careers, and to share in training and development experiences. Thus, they are likely to feel their talents are important to the employer and they have a better chance to utilize these talents. This often leads to greater employee satisfaction and its consequences, lower absenteeism, lower turnover, fewer accidents and higher quality of work.

(c) More effective EEO planning:-

Governments have increased their demands for equal employment opportunities (EEO). Information systems that focus on Human Resource planning help organizations formally plan employment distribution. Therefore, It is easier to complete the required government reports and respond satisfactorily to EEO demands using Human resource planning.

\section{HRP practices in nepalese business enterprises}

Human resource planning Practices in Nepalese Business enterprises are not so encouraging. Nepalese Business enterprises human resource planning is based on source 
force, favor- disfavor, lack of proper system, guess work, Nepotism and political ideology and so on.

Based on Agrawal (2009) Nepalese Business enterprises has a poor tradition of human Resource planning. Family owned and managed small and medium Business organization do not brother much about human resource planning. They prefer to hire their relatives, friends and "near and dear" ones. Even the big business houses and the large business organizations in the private sector lack proper human Resource planning. Human Resource planning is neglected by 'poltically appointed' managers in public Business enterprises. Overstaffing has made human Resource planning irrelevant in Government owned and public enterprises where as private sector is suffering from under staffing. Strategic planning is lacking in Business organizations. Human Resource planning is not linked with overall corporate planning.

Most Nepalese business organizations lack human Resource planning and managers give low priority to human Resource planning. Nepalese Business organizations lack right number and kinds of people at the right places. Nepalese Business organization lack proper demand forecasting in terms of number and skills of people required. These organizations also lack proper supply forecasts of human resource from inside and outside sources. Promotion and transfer are not planned in advance.

Most Nepalese Business organizations lack effective Human Resource information system. Effective job analysis is also lacking to lay down proper job descriptions and specifications. This has constrained Proper assessment of current human resources. Nepalese business managers do not do succession planning. Nepalese business organizations do not give proper attention to matching demand and supply forecasts to determine future shortages and surpluses.

\section{Conclusion}

Thus, in the above perspective Nepalese business enterprises needs strengthening human resource planning function effectively because procedures and techiniques of formal and systematic human resource planning are not followed properly. The adhock approach to human Resource planning should be replaced by systematic approach i.e. effective combonination of qualitative and quantitative approaches. Human resource planning cell need to establish in meduim and large sized business organizations. Top management should fully support human resource planning. Multinational business organization in Nepal do prepare formally systematic human resource planning and implement them. This will definitely have a positive impact for human resource planning in Nepalese business enterprises in coming years.

\section{Refrences}

Agrawal, G.R.(2009). Foundation of human resource management in Nepal. Kathmandu: MK publishers and distributors.

Beardwell, I. \& Holden, L. (1995). Human resource management: A Contemporary Perspective. New Delhi: Macmillan India Limited.

Chhabra, T.N.(2001). Human resurce management. New Delhi: Dhanpati Rai and Co. (p) Ltd.

Ivancevich, J.M. \& Glueck, W.F. (1983). Foundations of presonnel. Texas: Business publications.

Kharel, S.K. (2012). Fundation of human resource management. Kathmandu:Asia publication Pvt Ltd.

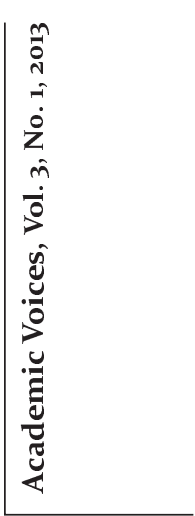

